INTERNATIONAL HIGHER EDUCATION - NUMBER 64 SUMMER 2011 Pages 21-22.

Private Higher Education in Pakistan

Nelofer Halai

Nelofer Halai is associate professor at the Institute for Educational Development, Aga Khan University, Karachi-75950, Pakistan. E-mail: nelofer.halai@aku.edu.

The demand for higher education all over the world, especially in the developing world, has fueled a tremendous growth of private universities. Countries such as India and China, for example, possess increasing space for private universities to flourish either independently or through private-public or private-international partnerships. However, almost without exception the private universities being established in developing countries are of poor quality, and in this case Pakistan is no exception.

\title{
Promotion by the State
}

Private university education constitutes a relatively recent development in Pakistan. The Aga Khan University was the first private university chartered in 1983, followed by Lahore University of Management Sciences in 1985. The growth of private universities was slow to start, but by 2000 the number had

jumped to 10 . This sector has now mushroomed to 60 , as compared to more than 70 in the public sector, and enrolls roughly a quarter of the student population. The private sector can play a major role in human-resource development in Pakistan if, together with enhancing access, the institutions can provide highquality education. At this point, the focus is on increasing access to larger numbers of students but not sufficiently on quality of education. 


\section{INCREASE IN ACCESS}

The growth in the number of both private and public universities has contributed to increased access for students. The Higher Education Commission, established in 2002 for improvement and promotion of higher education, has maintained accurate records of this growth. Enrollment of all students from 2002-2009 has tripled from 275,000 to 800,000. This number includes 115,000 students in private universities. Access to students in the 18-to-23-year-age range has more than doubled-from 2.2 percent to 4.7 percent in the last five years. This is close to the projected increase to 5 percent by 2010, and the longterm goal is to drive this to at least 10 percent. Hence, even this expansion is not sufficient to reach this goal and to keep pace with the demand as student enrollments grow sharply. By 2010, it is estimated, Pakistan will need to accommodate 1.3 million students at the tertiary level.

\section{QUALITY ISSUES}

The Higher Education Commission ranking of universities in Pakistan, conducted in 2006, illustrates that the quality of higher education offered by the private sector is of low quality. Lahore University of Management Sciences and the Aga Khan University-two private-sector universities at the top in the category of business, information technology, and health sciences-are the exception rather than the norm. Private universities are dogged with problems in all of the five elements, assessed by the Higher Education Commission, that contribute toward a low quality of educational experience. In particular, the paucity of qualified faculty and limited research and research output are two 
areas that need a great deal of attention. The lack of these two key qualities allow private universities to be seen as institutions that encourage rote memorization to pass an examination to obtain degrees rather than providing intellectual growth for students. In part, the proliferation is motivated by the relatively easy process to establish a university in the private sector, as Higher Education Commission's criteria are not very stringent or even rigorously implemented.

\section{MARKET ORIENTATION}

Unsurprisingly, private-sector investment is focused in areas that are in high demand but do not require large investments. While they are agile institutions able to respond to market needs in professional education, private universities have been less responsive to the needs of the country in other areas. For instance, considering the abysmal level of social sciences, Pakistan needs strong social science education. However, there appears to be little focus on this topic.

\section{Private Education Is EXPENSIVE}

Private higher education is also quite expensive. The average per capita income in Pakistan is US $\$ 370$ per year, while the average fees for a master's-degree program is estimated as at least US $\$ 1,000-1,500$ per year. Obviously these costs are beyond the capacity of an average Pakistani to afford. To bring into fold the student population that lacks the ability to pay, the private sector needs to put into place a transparent but vigorous program of financial support. 


\section{Private Schools}

Supporters of private higher education consider government institutions as wasteful and inefficient by hiring incompetent faculty who are not held accountable for their performance. Private universities are more efficient and can offer high-quality education at a lower cost than government institutions and can and will eventually start competing with international universities. The private school sector is portrayed as a system where private investment has enhanced both access and quality. However, this sector has also created "educational apartheid," where those who can afford the costs obtain access to quality education; but those who cannot are forced to study in low-quality government schools.

An exception has been demonstrated by private schools that have been funded by philanthropic agencies or educational trusts. Such schools have been able to provide high-quality schooling at a reasonable cost to students. In the same way, universities established on an altruistic basis rather than as business ventures have been able to uphold standards. Hence, encouraging the establishment of private universities by similar family trusts or philanthropic organizations might help to enhance access and maintain quality.

\section{A WAY FORWARD}

Thus, private university education in Pakistan, barring a few exceptions, is of low quality. If the situation is to change, active government engagement and involvement-by putting in place tough quality-assurance measures that are 
stringently implemented-are essential. The private universities can deliver both quality and access if the government policies encourage them to do so. 